doi: $10.12957 /$ childphilo.2020.46769

\title{
the child and the p4c curriculum ${ }^{1}$
}

\author{
stefano oliverio ${ }^{2}$ \\ university of naples federico ii, italy \\ orcid id: https:/ / orcid.org/0000-0001-9440-5516
}

abstract

In this paper I take my cue from what I suggest calling "Adamitic modernity." In this phrase I endeavor to capture a specific 'removal' of childhood that occurs in the Cartesian gesture of the enthroning of Reason. By drawing upon a reading of the major philosophical works of Descartes, I will argue that one of the main thrusts of his conceptual device is a deep-seated, and even anguished, mistrust of childhood and its errors. To put it in a nutshell: in Cartesian modernity, philosophy/science and childhood are at odds with each other. In the second step of my argument, I will show in what sense Dewey rehabilitates childhood and its form of experience by, thus, healing the rift between childhood and science (as his notions of inquiry and qualitative thought prove). This notwithstanding, Dewey was not ready to take the decisive step of thinking a philosophy for children. Precisely by activating and developing the significance of qualitative thought, Matthew Lipman was able, instead, to progress beyond Dewey. In this perspective, I will show how Lipman and Ann Sharp, while walking in Dewey's footsteps as far as their non-Cartesian interpretation of childhood is concerned, part company with him in their educational take on philosophy, and on how this results in a revamping of the way of construing the Deweyan relationship between the child and the curriculum.

keywords: philosophy and childhood; cartesian modernity; qualitative thought; dewey; lipman.

resumo

\section{a criança e o currículo de filosofia para crianças (fpc)}

Neste artigo, tomo minha sugestão do que sugiro chamar de "modernidade adamítica". Nesta frase, busco capturar uma "remoção" específica da infância que ocorre no gesto cartesiano da entronização da razão. Ao recorrer a uma leitura das principais obras filosóficas de Descartes, argumentarei que um dos principais impulsos de seu dispositivo conceitual é uma desconfiança profundamente arraigada, e até angustiada, da infância e de seus erros. Para resumir: na modernidade cartesiana, filosofia / ciência e infância estão em desacordo. No segundo passo do meu argumento, mostrarei em que sentido Dewey reabilita a infância e sua forma de experiência, curando assim a brecha entre a infância e a ciência (como provam suas noções de investigação e pensamento qualitativo). Não obstante, Dewey não estava pronto para dar o passo decisivo de pensar uma filosofia para as crianças. Precisamente, ativando e desenvolvendo o significado do pensamento qualitativo, Matthew Lipman conseguiu, em vez disso, progredir além de Dewey. Nesta perspectiva, mostrarei como Lipman e Ann Sharp, enquanto seguem os passos de Dewey no que diz respeito à sua interpretação não cartesiana

\footnotetext{
${ }^{1}$ This is a revised and enlarged version of a paper presented within the framework of the conference Philosophy and Childhood: Theory and Practice, organized by the Department of Education Science and the Department of Philosophy and Communication at the University of Bologna in December 2018.

${ }^{2}$ E-mail: stefano.oliverio@yahoo.it
} 
the child and the p4c curriculum

da infância, fazem parte dele na sua abordagem educacional da filosofia e de como isso resulta em uma reformulação da maneira de interpretar a relação deweyana entre a criança e o currículo.

palavras-chave: filosofia e infância; modernidade cartesiana; pensamento qualitativo; dewey; lipman.

\section{el niño y el currículum de filosofia para niños $(p 4 c)$}

resumen

En este artículo tomo mi propio ejemplo de lo que sugiero llamar "la modernidad adamita". Con esta frase me esfuerzo por capturar una "eliminación" específica de la infancia que ocurre en el gesto cartesiano de la entronización de la razón. Al recurrir a una lectura de las principales obras filosóficas de Descartes, argumentaré que uno de los principales impulsos de su dispositivo conceptual es una desconfianza profundamente arraigada, e incluso angustiada, en la infancia y sus errores. En pocas palabras: en la modernidad cartesiana, la filosofía/ciencia y la infancia están en desacuerdo entre sí. En el segundo paso de mi argumentación, mostraré en qué sentido Dewey rehabilita la infancia y su forma de experiencia, zanjando así la brecha entre la infancia y la ciencia (como lo demuestran sus nociones de investigación y pensamiento cualitativo). A pesar de esto, Dewey no estaba listo para dar el paso decisivo de pensar en una filosofía para niños. Precisamente al activar y desarrollar la importancia del pensamiento cualitativo, Matthew Lipman pudo, en cambio, progresar más allá de Dewey. En esta perspectiva, mostraré cómo Lipman y Ann Sharp, mientras siguen los pasos de Dewey en lo que respecta a su interpretación no cartesiana de la infancia, se unen a él en su visión educativa de la filosofía y cómo esto resulta en una renovación de la forma de construir una relación deweyana entre el niño y el currículo.

palabras clave: filosofía e infancia; modernidad cartesiana; pensamiento cualitativo; dewey; lipman. 
the child and the p4c curriculum ${ }^{3}$

\section{introduction}

In his introduction to the proceedings of a conference held in Rio de Janeiro, "Devir-criança da filosofia: infância da educação," Walter Kohan (2010) has beautifully elaborated on a Foucauldian theme to indicate the complexity of the bond between childhood and philosophy. His starting point is the paragraphs that conclude the manuscript of the course on Le courage de la vérité, which Foucault delivered in 1984, a few months before passing away. In particular, Kohan emphasizes the very last sentence: " $[T]$ here is no establishment of the truth without an essential position of otherness; the truth is never the same; there can be truth only in the form of the other world and the other life" (Foucault, 2008, p. 311; English translation in Foucault, 2011, p. 340). This sentence is the culmination of the distinction between two main philosophical modalities in which the notions of Socratic epimeleia (care of the self) and parrhessia (the saying of the truth) developed, namely "the Platonic modality that [i]n a very significant way [...] accentuates the importance and extent of the mathemata" and "the Cynic modality [that] reduces as strictly as possible the domain of the mathemata [and] gives knowledge of self the privileged form of exercise, test, and practices of endurance" (Foucault, 2008, p. 310. English translation in Foucault, 2011, p. 339). What is at stake, then, in these final words of Foucault, is the unique regime of relations obtaining between truth and otherness, mathēmata and life, knowledge and care.

The ingenious interpretive move of Kohan is to insinuate that we should engage with the question of childhood and philosophy, and with that of learning and teaching, through the lens of the Foucauldian formula "no truth without otherness." Even more: childhood could be the domain where truth and otherness may meet or,

\footnotetext{
3 I draw here upon some reflections that I presented in the "Devir-criança da filosofia: infância da educação" conference held in Rio de Janeiro in 2010 and mentioned at the beginning of this paper.

4 This sentence appears also on the back-cover of the French edition of the volume and this testifies to its testamentary value.
} 
the child and the p4c curriculum

to put it more accurately, where they may experience that form of (possibly inescapable) connection captured in the "not ... without" relation.

Against this Foucauldian-Kohanian backdrop, the present paper will tackle a philosophical constellation in many respects alien to it, namely educational pragmatism (and more specifically John Dewey's thought) and its reconstruction through the project of Philosophy for Children in the IAPC tradition. The paper addresses what in another context has been called "the Deweyan ulteriority of Lipman" (Oliverio, 2012, p. 55). This phrase endeavors to epitomize that movement of going beyond Dewey that Lipman ascribed to his undertaking:

I took from Dewey the idea that a classroom session must begin with something that stimulates the interest of the children and then leads them to reflect on the meaning of their experience [...] What Dewey didn't realise was that a discipline such as philosophy, which he had right under his nose, so to speak, could be used for this purpose. In this sense, Philosophy for Children is a Deweyian [sic] way of going beyond Dewey. (Lipman, quoted in Striano, 2012, p. 522)

As argued elsewhere (Oliverio, 2012), this ulteriority is anything but trivial insofar as it has everything to do with precisely the establishment of an intimate relation between philosophy and childhood. This requires, on the part of Lipman, the overcoming of some facets of Dewey's understanding of philosophy, while accepting many dimensions of the latter's revolution in the view of childhood by, however, accomplishing it in a direction unanticipated by Dewey. The question that will be engaged with in this contribution is how and to what extent this 'ulteriority' reverberates on the relationship between the child and the curriculum or, more specifically, whether and how the child and the P4C curriculum exceed the horizon outlined by Dewey (1976) in his epoch-making text of 1902.

The argumentation will unfold in two stages: first, I will rehearse some motifs treated in more detail (and somewhat differently) in my aforementioned article and I will illustrate in what sense Dewey represents a major break with what could be defined as the Cartesian-Adamitic modernity and how Lipman may have taken even a step further on the Deweyan track; then, in section 2, I will connect this break with 
the issue of the child and the curriculum, by situating my argument within the Foucauldian-Kohanian horizon from which I have taken my cue.

A caveat is opportune: it could appear foolhardy to combine the DeweyanLipmanian and the Foucauldian-Kohanian thrusts, as it could be legitimately argued that they represent two sharply demarcated alternatives. While not gainsaying the strength of this objection and, indeed, accepting it as a welcome warning not to dilute the differences of distinct argumentative devices into a kind of 'homogenous' sameness (which would, moreover, fly in the face of the Foucauldian-Kohanian 'principle' just stated), I would like to specify two things: first, there are significant relations between Dewey and Foucault, as the scholarly research, both at the purely theoretical (see Rabinow, 2011, 2012; Koopman, 2009) and at the biographical level (see for instance Deledalle, 2002), has highlighted. Indeed, the reading of Dewey's works in experimental logic and the discussions with Gérard Deledalle in Tunis on the philosophy of Dewey were an important influence for Foucault in the development of key conceptual tools (see Renier, 2016). In this perspective, by joining this Wirkungsgeschichte on the relation between Dewey and Foucault, it would be interesting to explore whether and to what extent it could offer insights also to revisit that Deweyan practice which P4C in the IAPC tradition is.

However, this is an undertaking which largely exceeds the scope of the present paper, which has, instead, a much more modest goal (this is my second point): without vindicating any complete overlapping between the two aforementioned thrusts, I want to deploy the 'Foucauldian-Kohanian principle' in order to start outlining a way of inhabiting the question of the curriculum, by avoiding some possible pitfalls of Dewey's stance. In other words, I will employ it to fathom a possible understanding of the Lipmanian 'ulteriority', when the issue of the curriculm is addressed. In this sense, the 'Foucauldian-Kohanian' line, precisely in its 'exorbitant' (literally understood) character, may serve as a way to 'displace' the Lipmanian understanding of the curriculum outside the orbit of some unfortunate 
the child and the p4c curriculum

statements of Dewey (and, thereby, it could help us to elicit a more robust Deweyan view of the-child-and-the-curriculum issue).

\section{1. beyond the cartesian-adamitic modernity: the deweyan discovery of the inquiring child}

In order to portray the profile of the Cartesian modernity and its dismissal of children's knowledge I will start with some valuable reflections of David Kennedy $(2006)^{5}$, who has pointed out how the fool is "a perennial, ineradicable figure in Western consciousness" (p. 69) because s/he represents what has been repressed and eliminated from the hegemonic worldview and, at the same time, what could throw it into a crisis. S/he strikes a discordant note at the court of the King (that is, of the Only Legitimate Knowledge), s/he is the spokesperson for 'other' and even opposite knowledge demands, which are not acknowledged (if not openly banned), and for "forms of forbidden, transgressive knowledge" (Ibidem). S/he is - to put it in a nutshell - the one who announces that "the king is naked" (Ibidem).

This last reference to the well-known Andersen fable (The Emperor's New Clothes) should not sound surprising: indeed, in the history of Western civilization children are one of the main 'embodiments' of the figure of the fool so understood: "Like the fool, the child's power is in his very powerlessness. He is a sign which announces what has been left out of the grown-ups' bargain with time, self, and world-picture" (pp. 69-70). As a consequence, "[a]ny hegemonic world-picture has a special interest in children. Children are, in a way, the proof-text for any worldpicture. If you can show children are arriving at your world-picture 'genetically', it can be understood as truth rather than ideology" (p. 70).

This last remark of Kennedy is of great interest and worth being considered in depth. It is to be highlighted that such a hegemonic argumentative device does not confine itself to stating that, if a specific worldview is true, then children have to be

\footnotetext{
${ }^{5}$ I draw here upon some reflections that I presented in the conference mentioned at the beginning of this paper.
} 
educated according to it. The assumption is, in reality, much more radical (and more challenging for philosophers of education): what is maintained is that children will reach the ruling worldview genetically - and not through education - because it is true. In such a theoretical device education is an entité negligeable compared to the development of "native capacities"; it can at most play a role in fostering or thwarting their unfolding but not in their coming into being. True knowledge is a sort of developmental destiny, which has almost nothing to do with educational practices.

Excluded from any 'constructive' role, education continues to play only a 'preemptive' one: it has to prevent the sequence of cognitive stages from not being respected, from stopping at a stage before the full blossoming of Truth. In this view, children do have native capacities in themselves that, if not disturbed in their development, will lead to the stage of true knowledge (that is, the ruling one): education has only to support these capacities. Otherwise, it would be an ideological education insofar as it does not follow their natural development. In order not to be 'ideological', education has to be secondary, that is, it has to second and uphold what is the primary factor in the cognitive development of children, what ushers them into the Kingdom of Truth.

In Kennedy's reconstruction, such a theoretical device is at work in the Piagetian genetic epistemology and sanctions the supremacy of the scientific worldview:

[T]here is still the assumption among most cognitive developmentalists [...] that the child, under the influence of culture to be sure, is nevertheless moving through a progressive, developmental, hierarchically staged series of epistemological and ontological perspectives, which will eventually, if development is not stunted either by culture or genetic factors, result in a world picture which is more 'objective' than the one they started with, a truer picture of how things really are. And that picture is, of course, the scientific world-picture. (Kennedy, 2006, p. 71)

The penalty paid for this approach is the questioning of children's ontology and epistemology, which are informed with a sort of pre-modern animism and anthropomorphism rather than with the mechanicism of Cartesian science. According 
the child and the p4c curriculum

to Kennedy, the concurrence of the 'birth' of modern science and the invention of childhood is meaningful: by inventing childhood a way was found to delocalize a cognitive style which - before modern science - belonged to all people, in a specific age of their life. In this sense, the separateness of children and adults parallels that between the pre-scientific world-picture and the scientific outlook. Children grow up and become adult to the extent that they become able to understand science and vice versa - the capacity of understanding science, by taking leave of animistic and anthropomorphic views, is the hallmark of their coming of age, of their Mündigkeit, to use the Kantian (1998) expression. All this relies upon one assumption, as is evident, namely that children as such are outside science (the latter understood as the realm of true knowledge).

Within the horizon of these insights of Kennedy, I would like to suggest that the Cartesian device, which will be discussed in the next paragraphs, instantiates precisely this sharp separation. Indeed, the Cartesian gesture of the enthroning of Reason is predicated upon a specific 'removal' of childhood. To adapt a famous Freudian motto, it is possible to capture the process culminating in the cogito in the formula "where the child was, there science shall be." Indeed, one of the main thrusts of Descartes's conceptual device is a deep-seated, and even anguished, mistrust of childhood and its errors, and one of the chief driving forces of the procedure of radical doubt is that of discarding any debris of childhood in order to attain the clarity of knowledge. If, as Heidegger (1956) maintains, at the beginning of any thought there is a specific mood, a Stimmung, then it has to be stated that at the beginning of the Cartesian enterprise there is not the cogito (which is an outcome) but a definite Stimmung: the fear of being deceived (Alquié, 1950, p. 55) - of being fooled! and, as a consequence, the quest for certainty (Dewey, 1984a), the pursuit of the myth of stability (Toulmin, 2001).

Descartes is all the more anguished by this fear the closer are the sources of the (possible) deception. Indeed, the first reason why we as human beings are exposed to the risk of being deceived/fooled is that we used to be children. It is the child - the 
fool! - inside (and behind) us who makes us vulnerable, credulous, deceivable/'foolable' and, therefore, incapable of well-founded knowledge. Descartes's primary effort is, then, to remove the status of childhood (Alquié, 1950, p. 55 ) and to overcome the deception to which the child is condemned on account of her/his epistemic minority. In his escape from childhood Descartes is radical and regrets the loss of the 'Adamitic' condition because Adam and Eve "were not born as infants but they were created as adults" (Descartes, 1908c, p. 100).

The strategy of doubt (which I cannot reconstruct here in its stages in detail) is presented, in the Principles of Philosophy, as a way of obviating the epistemic deficiencies related to the condition of childhood:

As we were at one time children, and as we formed various judgments regarding the objects presented to our senses, when as yet we had not the entire use of our reason, numerous prejudices stand in the way of our arriving at the knowledge of truth; and of these it seems impossible for us to rid ourselves, unless we undertake, once in our lifetime, to doubt of all those things in which we may discover even the smallest suspicion of uncertainty. (Ibid., p. 5. See also Descartes, 1908a, p. 13) ${ }^{6}$

In a sense, in this view, childhood is the antithesis of Reason: not only are its autonomous forms of knowledge not recognized but it is considered as a negative stage to be abandoned in order to get to the kingdom of science. When in the Discourse on the Method Descartes (1908a) states that only with the coming of age did he begin to doubt, he may be interpreted as meaning this: in order to pass the threshold of true knowledge, one needs to become an adult, to abandon childhood, to throw all childhood knowledge into doubt, and to deny oneself as a being who was once a child. Descartes seems to aspire to a kind of maturity which is absolute, in the sense that it excludes any previous immaturity or Unmündigkeit, that is, any childhood. This conceptual device is poles apart from the 'Foucauldian' principle "no truth without otherness" through which Kohan reads the relationship between philosophy and childhood. Indeed, it is a 'Platonic' stance, in the Foucauldian sense,

6 For the English translation I have drawn upon the version retrievable from http://www.classicallibrary.org/descartes/principles/01.htm. Access November 16 ${ }^{\text {th }}, 2019$. 
the child and the p4c curriculum

to the extent that philosophy should be without childhood and, therefore, by accentuating the importance and significance of the mathemata, has to be thought of as fundamentally mathematic.

By adapting a consideration of Heidegger (1987), we should guard ourselves against misconstruing this affirmation: the Cartesian philosophy is not mathematic because it deploys the method of mathematics but, conversely, it ends up marshalling the method of mathematics and aspiring to the mathesis pura because it relies upon a 'mathematic' stance. As Heidegger (1987) argues, 'mathematic' comes from ta mathemata, that is, things insofar as they are learnable: "[They] are the things insofar as we take cognizance of them as what we already know in advance [...] Such a proper learning is thereby an extremely remarkable taking, a taking where the one who takes takes only what fundamentally he already has" (p. 56). In modern science - Heidegger notes - this 'original learning' as a taking-cognizance-of-what-onealready-knows is a mente concipere (p. 70), a conceiving by virtue of the mind, which consists in opening up a realm of definite (and so investigable) events and objects by projecting a ground plan of processes and objects which will be investigated (see also Heidegger, 1994). The world approached through mathemata is not the world of our primary existential dealings, experienced as a matter of concern, but it is the world appropriated as the object of knowledge by a subject who is an epistemic agent pursuing the certainty of (scientific) truth. And this world disclosed by science is the only one ultimately real.

The Cartesian Meditations (1908b), in their unfolding, are the first and still most revealing account of this stance: in the First Meditation, alarmed by the mendaciousness of the senses and distrustful of the certainties provided by our embeddedness in the everyday world, that is, wary of his own exposition to the fallacies ultimately dependent upon the fact that he had been a child, Descartes arrives at the fiction of the evil genius. The latter is explicitly presented as a supposition and it is the very antecedent of the clarity of the cogito: only to the extent that the evil genius has cleared the domain of knowledge of any possible 'childish' 
deception, by sinking the whole world into a sort of baroque reverie (Ibid., pp. $22 \mathrm{ff}$.), will the cogito be able to emerge as the supreme court for certainty and as a guarantee for knowledge. In other words, in order not to be fooled by what can affect him (on account of a tendency to prejudices coming from childhood), Descartes recurs to a self-inflicted fiction which prevents him from being the passive casualty of the deceptions of the world.

The strategy of dis-engagement from the world realized in the First Meditation is coextensive with the removal of any childhood traces (including all knowledge acquired at school [see also Descartes, 1908a, pp. $4 \mathrm{ff}$.]) and it is the premise of the attainment of the cogito in the Second Meditation, which will act as the springboard to the mathesis pura. Once he is in possession of the latter, Descartes endeavors, in the Sixth and final Meditation, to recover what he had let sink into the reverie, that is, the common world perceived by the senses. From this point of view, the Sixth Meditation is specular to the First: what in the latter was cast in doubt and turned into a fable through the evil genius is now recovered, but only insofar as the intellect guarantees it, that is, via the mathemata. In our relationship to the world - if it is to be a relationship founded on the rock of truth (Descartes, 1908a, p. 29) - where the child was, there science must be.

It is this 'Adamitic-mathematic' view of science, typical of a modernity pursuing the Myth of Stability (Toulmin, 2001) that Dewey overturns. In the preface to the first edition of How We Think, he writes:

Th[e] scientific attitude of mind might, conceivably, be quite irrelevant to teaching children and youth. But this book also represents the conviction that such is not the case; that the native and unspoiled attitude of childhood, marked by ardent curiosity, fertile imagination, and love of experimental inquiry, is near, very near, to the attitude of the scientific mind. (Dewey, 1986, p. 109. Emphasis added).

A statement like this can obviously be interpreted merely as a rhetorical move aiming to make the idea of education for reflective thinking as education through inquiry both plausible and appealing to an audience that could be not ready to easily accept it. Richard Rorty (1986, p. ix) has called How We Think "the bible of those who 
the child and the p4c curriculum

came to be called 'progressive' educators"; however, far from thus construing it just as a popularization of Dewey's tenets in logic, he has sagaciously remarked:

But the notion of 'popular exposition' is misleading and rather unDeweyan [...]. Dewey was not inclined to distinguish between serious, 'professional,' work and 'popularization.' For him, to write up old ideas for a new audience was to produce new ideas, new instruments for advancing the projects he was promoting. He thought of himself as reshaping tools for use on new materials rather than as providing 'applied' versions of a previously 'pure' body of knowledge. He did not think of his fellow philosophy professors as his 'real' audience, nor of elementary school teachers [...] as supplementary constituencies to be supplied with a 'popular,' less demanding, version of the same material. (Ibid., pp. ix-x)

In this perspective, the previous Deweyan statement is something more than a merely rhetorical expedient and it can be legitimately read as making a theoretical point: we should replace the Cartesian view of science as purified from any childhood in its quest for certainty, with the awareness of the proximity of science and childhood and of their elective affinities: where science is, there childhood is as well and, moreover, not as an undeletable sign of fallacy or a never fully unavoidable - and, therefore, constantly to be overcome - proclivity to error, but rather as the very source of some of the most important habits and dispositions necessary for the scientific undertaking. While the Cartesian scientist wanted to be like Adam and Eve, insofar as they had never been children, the Deweyan scientist is ready to recognize the inquiring child as her/his forebear.

It is to note that this proximity is in terms of attitude and not in terms of possession of any 'truth'. In this sense, on the one hand, Dewey is anti-Cartesian because he denies the idea that there is an unbridgeable gap between childhood and science, so that the establishment of the latter would require the deletion of the former (which, for Descartes, is unfortunately never fully accomplishable, by thus exposing us to error); and, on the other, the Deweyan view, as I read it, is not stating that children's thinking carries value because it arrives at the same conclusions as science (at 'the true picture of how things are', to adopt Kennedy's phrasing). 
Accordingly, the Deweyan conceptual device is not doomed to be one more instance of the position denounced by Kennedy (2006).

Perhaps we could even take a step further, possibly twisting Dewey's argument a little bit but not betraying it: not only is he highlighting the affinities between the attitude of childhood and the scientific mindset, but he may be ready to recognize the interlacement between some dimensions of the childhood worldview as Kennedy (2006) depicts it - and the scientific one. In order to make this point, I want to introduce a notion which is crucial in Dewey, that of qualitative thinking. Dewey's starting point is that " $t]$ he world in which we immediately live, that in which we strive, succeed, and are defeated is preeminently a qualitative world" (Dewey, 1984b, p. 243). As a consequence, "the immediate existence of quality, and of dominant and pervasive quality, is the background, the point of departure, and the regulative principle of all thinking" (Ibid., p. 261). Dewey distinguishes between

something called a 'situation' and something termed an 'object.' By the term situation in this connection is signified the fact that the subject-matter ultimately referred to in existential propositions is a complex existence that is held together in spite of its internal complexity by the fact that it is dominated and characterized throughout by a single quality. By 'object' is meant some element in the complex whole that is defined in abstraction from the whole of which it is a distinction. The special point made is that the selective determination and relation of objects in thought is controlled by reference to a situation - to that which is constituted by a pervasive and internally integrating quality, so that failure to acknowledge the situation leaves, in the end, the logical force of objects and their relations inexplicable. (Ibid., p. 246)

The genuine subject-matter of inquiry is, accordingly, (the quality of) the situation and the latter "is not and cannot be stated or made explicit. It is taken for granted, 'understood,' or implicit in all its propositional symbolization. It forms the universe of discourse of whatever is expressly stated or of what appears as a term in a proposition" (Ibid., p. 247). Indeed, "[t]he problem is had or experienced before it can be stated or set forth; but it is had as an immediate quality of the whole situation. The sense of something problematic, of something perplexing and to be resolved, marks the presence of something pervading all elements and considerations. Thought is the 
operation by which it is converted into pertinent and coherent terms" (Ibid., p. 249. Emphasis added).

By appropriating this set of ideas in a partly idiosyncratic way and referring it to some of the aforementioned arguments, I want to suggest a specific interpretation of qualitative thought: first, 'objects' as Dewey depicts them can be construed as mathemata, something that, while being legitimate as interpretive tools and discriminations of a situation as a complex existential constellation, become a source of intellectualistic error, once they are absolutized and taken as something already known in advance, prior to any engagement with a qualitative world and even as the very condition of any true access to it, that is, an access that does not risk falling prey to its qualitativeness but addresses it via the 'objectification' of the latter. Secondly, in our thinking we start with a qualitative world or, more accurately, with problems had as the immediate quality of a whole situation, precisely because we have been children. This status, which for Descartes was a mark of epistemic inferiority in comparison with our forebear Adam, is - in the reading of Dewey that I have been proposing the very condition of our thinking. For Dewey, Adam would not have been able to think better but rather he could not have thought at all, in any humanly significant meaning of the word thinking. Accordingly, if science is one of the main manifestations of human reflective thinking, it is intimately interlaced with a 'childhood moment.'

The issue of "qualitative thinking" is at the very origin of Lipman's project of P4C and represents also a sort of (theoretical and existential) turning point, as a few sentences in his autobiography attest, when speaking of his reaction to an exhibition of children's art. His testimony deserves to be quoted in some length:

Could there not be certain topics in which children's thinking approached or perhaps even exceeded the thinking of adults? Could there not be in children what Dewey called 'qualitative thought' thought in sounds and in colors, for example, and not just in words, concepts or logical relationships? These were questions I would pursue with vigor in coming years, especially once I transferred from Columbia to Montclair State College. The children's art exhibition at Summerhill touched off in me a lively skepticism about the reduction 
of all thinking about thinking to linguistic discourse (a phenomenon that was very popular in the philosophy of those days). And it added to the respect that was growing in me for the curious power of the thought of children, a power that I began to suspect had been enormously underrated by psychologists. (Lipman, 2008, pp. 105-106)

We can interpret the transfer from Columbia to Montclair as a metaphor of the passage not only from pure philosophy to philosophy as an educational 'tool' but also, and more specifically, from an analytical understanding of philosophical activity - which, however, has arguably left significant traces in the IAPC curriculum, especially in the Manuals - to a broader view, pivoting on Dewey. From the latter Lipman drew many insights (the idea of inquiry and of an activist pedagogy being obviously in the foreground) and, more fundamentally, according to the reading here provided, he situated himself in the wake of the Deweyan overturning of the Cartesian Adamatic-mathematic view of science (predicated upon a dismissal of children's thinking). The child as an inquirer-one of the hinges of Dewey's educational theory-is the very condition of possibility for the very project of Philosophy for Children to arise.

And, though, the child as a philosophical inquirer is a typically Lipmanian (and Sharpian) discovery, something that, in many respects, had to remain unanticipated in the classic Deweyan framework. I will not rehearse the meta-philosophical motifs that may have prevented Dewey from making this discovery - that is, the reasons ultimately linked not with an alleged epistemic minority of children but rather with the idea (in many respects Hegelian) that he had about the philosophical undertaking as such (see Oliverio, 2012, pp. 63-66). As argued in another paper (Oliverio, 2015), Lipman could educationally operationalize this discovery through the invention of a curriculum and, more specifically, of philosophical novels, which enabled him to 'resituate' (the history of) philosophy, that is, to engage with philosophical problems and leading ideas not as 'objects' (in the aforementioned Deweyan sense) but rather as something emerging from existential situations - portrayed in narrative modalities. This was a turning of the philosophical tradition inside-out and it consisted also in bringing to the fore what I have here called the 'the childhood moment' of the process 
of reflective thinking. In this way, the tradition of philosophy could be activated within a project of education for complex thinking. Thus, Lipman and Sharp were able to go beyond Dewey (appealing to philosophy as a resource for educating thinking) along Deweyan lines (by drawing upon the Deweyan insights about qualitative thought and inquiry).

In the following section, I will endeavor to show how this move could be read in reference to the issue of the relationship between the child and the curriculum, as Dewey depicts it. In particular, I will argue that an understanding of this relationship in terms of the Foucauldian-Kohanian principle "no truth without otherness" (and, therefore, "no philosophy without childhood") can help to eschew the possibly slippery consequences of some Deweyan formulations.

\section{2. beyond the 'mathematic' curriculum: 'no philosophical curriculum without otherness'}

The creators of the IAPC curriculum recognized very early that, in order to integrate philosophy "into the elementary and secondary levels of education [...] there would be needed [...] a concerted effort to prepare teachers to teach philosophy, and a new curriculum" (Lipman, Sharp, \& Oscanyan, 1980, p. 51. Emphasis added). In devising a curriculum - they argue - an important ingredient

to its success is proper timing in the introduction and sequential presentation of materials. Teaching philosophy involves eliciting themes from students and then repeatedly returning to them, weaving them into the fabric of the students' discussions as the classes proceed. If one looks at the entire curriculum, one will notice that the philosophical themes introduced in one novel occur and reoccur, each time in a little more depth, breadth, and sophistication. Unlike "atomistic teaching," which introduces a segment of knowledge, drills for it until it is mastered by the students, and then moves on to something new, this "organic" approach to teaching touches lightly on philosophical concepts in the beginning and then slowly builds on a deeper understanding of the same concepts as they relate to recurrent motifs. (Ibid., p. 82).

This stress upon the importance of a curriculum and its construction does not imply a dismissal of the role of the teacher or the fatal conceit of being able (and 
having) to draw upon "'teacher proof' texts" (Murris, 2016) or the reduction of the significance of the role of the community of philosophical inquiry: "On the contrary, it is assumed that philosophical learning occurs primarily through interaction between the children and their environment-and that environment consists primarily of the physical classroom, other children, parents, relatives, friends, people in the community, the media, and the teacher" (Lipman, Sharp, \& Oscanyan, 1980, p. $83)$.

A statement like this is fairly Deweyan and, in the circuit that it establishes between the curricular materials, the environment, the teacher and children, it echoes, in many respects, the end of his epoch-making The Child and the Curriculum: "Now, the value of the formulated wealth of knowledge that makes up the course of study is that it may enable the educator to determine the environment of the child, and thus by indirection to direct. Its primary value, its primary indication, is for the teacher, not for the child" (Dewey, 1976, p. 291). Can we construe the work of Lipman and Sharp on the creation of the IAPC curriculum through the lens of the Deweyan conceptuality? Or, rather, should their 'thematic' ulteriority (namely the fact that they mobilize a subject-matter like philosophy) result also in an innovation in the way in which they read the relationship between the child and the curriculum? Or, more cautiously, without representing a thorough innovation in the Deweyan view, does the very creation of a 'philosophical' curriculum for children allow us to detect some criticalities in his way of framing the-child-and-the-curriculum issue?

In one of her latest interviews, Ann Sharp has forcefully spelled out her understanding of philosophy and its educational potential:

When I think of philosophy, I think of a myriad of skills married with a history of ideas that have created our intellectual legacy, a legacy to which every child is entitled. These skills involve critical, creative and caring inquiry, being able to recognize, frame, formulate and solve our common problems by creating new ideas, testing these ideas in practice and knowing how to self-correct when the ideas no longer serve us well. Such inquiry is philosophical because it forces the student to consider the ethical, aesthetic, logical, political and social dimensions of the problem at hand. (Striano \& Oliverio, 2012, p. 39) 
the child and the p4c curriculum

At one level, Sharp can be interpreted as insinuating that (history of) philosophy as a repertoire of skills and themes represents "the formulated wealth of knowledge that makes up the course of study" (to adapt the aforementioned phrase of Dewey) that can be marshalled to cultivate some abilities to engage philosophically with the problems that children, as well as each of us, may encounter in their experience of the world. In this perspective, we would remain within the Deweyan horizon.

The statement of Dewey quoted above continues, however, in this way:

[The curriculum] says to the teacher: Such and such are the capacities, the fulfillments, in truth and beauty and behavior, open to these children. Now see to it that day by day the conditions are such that their own activities move inevitably in this direction, toward such culmination of themselves. Let the child's nature fulfill its own destiny, revealed to you in whatever of science and art and industry the world now holds as its own. (Dewey, 1976, p. 291. Emphasis added)

When speaking of (history of) philosophy as an intellectual legacy, is Sharp thinking in terms of "destiny," as in the above mentioned sentence of Dewey? Or should we find a better vocabulary to express the relationship between the child and the curriculum? Is not the invention of the P4C curriculum a major example of a recontextualization or redescription of Dewey's tenets as Rorty would call it?

As will be shown in the following paragraphs, the vocabulary of the curriculum as "the destiny" recurs in The Child and the Curriculum and, thus, it might be legitimately taken as belonging to the deep mechanism of its conceptual device. I am ready to recognize that I am going to provide (at least in some points of my argument) a particularly uncharitable reading of Dewey, which possibly exaggerates the importance and scope of what could be no more than simply an unfortunate phrasing. ${ }^{7}$ However, this misreading, perhaps inadequate as a philologically correct

\footnotetext{
7 I want to express my gratitude to Joshua Forstenzer who warned me against the risks of such an uncharitable reading, when I presented this paper at the conference mentioned in footnote 1 . He was certainly right in his comment, when emphasizing that it may be a little reckless to base one's own argument on the phrasing of Dewey, considering that the latter's literary style is not always his strength. This opportune remark notwithstanding, I think that - merely unfortunate as the phrasing may be - it reveals something significant or, at least and more cautiously, that focusing on its literal
} 
interpretation, can help us to spotlight what is at stake in the invention of a philosophical curriculum addressed at the child as a (philosophical) inquirer.

Dewey starts his argument with the denial of any irreducible contrast between the child and the curriculum (which would explain the incessant struggle taking place in the educational field between the advocates of children's interests and the supporters of an organization of studies predominantly, if not exclusively, based upon the structures of subject-matters), In contrast, Dewey argues,

the child and the curriculum are simply two limits which define a single process. Just as two points define a straight line, so the present standpoint of the child and the facts and truths of studies define instruction. It is continuous reconstruction, moving from the child's present experience out into that represented by the organized bodies of truth that we call studies. [...] Hence, the facts and truths that enter into the child's present experience, and those contained in the subject-matter of studies, are the initial and final terms of one reality. To oppose one to the other is to oppose the infancy and maturity of the same growing life; it is to set the moving tendency and the final result of the same process over against each other; it is to hold that the nature and the destiny of the child war with each other. (Dewey, 1976, p. 278. Emphasis added)

It is plausible to construe this passage-with its emphasis upon the linearity and unity of one process connecting the two poles-only as an attempt to disarm an illegitimate dichotomy and to defuse one of the many either-ors plaguing mankind, which "likes to think in terms of extreme opposites" (Dewey, 1988, p. 5), as we read at the beginning of Experience and Education. Moreover, bearing in mind that Dewey, in Democracy and Education, clearly opposes the Hegelian notion of development as "the gradual making explicit and outward of what is [...] wrapped up" (Dewey, 1980, p. 62) to his own logic of growth as reconstruction, it may be unfair to say that speaking of the curriculum - the logical structuration of knowledge - in terms of a destiny for children's nature smacks a little bit (too much) of Hegelianism. And it would be even more foolhardy to see in these formulations of Dewey a lapse into that kind of

formulation may help us understand how the relationship between the child and the curriculum should be framed, if one does not want to capitulate to unwelcome outcomes. 
the child and the p4c curriculum

developmental thought stigmatized, as mentioned in the previous section, by Kennedy (2006), insofar as it winds up gainsaying the epistemic rights of children.

These caveats notwithstanding, it is difficult to resist the impression that, in his endeavor to overcome a dangerous opposition, Dewey establishes a linear connection, which may be problematic for all subject-matters, and certainly inadequate to capture the specificity of a philosophical curriculum.

Before discussing this point, I want to continue the reconstruction of Dewey's argument. The further step consists in distinguishing

the logical and the psychological aspects of experience-the former standing for subject-matter in itself, the latter for it in relation to the child. A psychological statement of experience follows its actual growth; it is historic; it notes steps actually taken, the uncertain and tortuous, as well as the efficient and successful. The logical point of view, on the other hand, assumes that the development has reached a certain positive stage of fulfillment. It neglects the process and considers the outcome. It summarizes and arranges, and thus separates the achieved results from the actual steps by which they were forthcoming in the first instance. (Dewey, 1976, p. 283)

That this way of presenting the difference between the logical and the psychological aspects does not entail any 'developmentalist' drift is proved by the specification which Dewey soon proposes:

The logical is not set over against the psychological. The surveyed and arranged result occupies a critical position in the process of growth. It marks a turning-point. It shows how we may get the benefit of past effort in controlling future endeavor. In the largest sense the logical standpoint is itself psychological; it has its meaning as a point in the development of experience, and its justification is in its functioning in the future growth which it insures. Hence the need of reinstating into experience the subject-matter of the studies, or branches of learning. It must be restored to the experience from which it has been abstracted. It needs to be psychologized; turned over, translated into the immediate and individual experiencing within which it has its origin and significance. (Ibid., p. 285)

This passage makes it clear that we must not conflate Dewey's argument with the kind of 'genetic' view criticized by Kennedy (2006). And, in many respects, also the vocabulary of "the destiny" seems to disappear: here Dewey is not turning the logical organization of knowledge into a sort of final stage of a process of which the 
experience of children is the square one. Conversely, he is insinuating that the logically arranged subjects should be taken as tools to promote further experiences experiences which will be all the more meaningful and intelligently directed the more they will be able to draw upon past knowledge not as a definitive truth but as an instrument of an intelligent reconstruction of experience and, thus, of growth.

In this sense, the very dynamics of psychologization, which is here invoked, is different from that reduction of the nature (= the psychological) to the destiny (= the logical), which seemed to emerge in the concluding sentences of The Child and the Curriculum, at least according to an admittedly uncharitable reading of them. Indeed, the work of psychologization may be interpreted as opening up for children the possibility of creatively appropriating a cultural heritage in order to make it the pivot of the reconstruction of their own experience.

At the same time, by once again adopting an uncharitable perspective, one may ask whether this image of the curriculum does not risk being ultimately 'mathematic' in the acceptation introduced in the previous section. Is not the curriculum so understood the organization of mathemata? Does it not offer a series of 'objects' (in the meaning mentioned in reference to qualitative thought), which is the task of the teacher to 'resituate' or, better, to help the student to resituate within the horizon of experience? On the one hand, this may be the outcome of a possible reading of the Deweyan distinction between two aspects of a study,

one for the scientist as a scientist; the other for the teacher as a teacher. These two aspects are in no sense opposed or conflicting. But neither are they immediately identical. For the scientist, the subject-matter represents simply a given body of truth to be employed in locating new problems, instituting new researches, and carrying them through to a verified outcome. To him the subject-matter of the science is selfcontained. [...] The problem of the teacher is a different one. As a teacher he is not concerned with adding new facts to the science he teaches; in propounding new hypotheses or in verifying them. He is concerned with the subject-matter of the science as representing a given stage and phase of the development of experience. His problem is that of inducing a vital and personal experiencing. Hence, what concerns him, as teacher, is the ways in which that subject may become a part of experience; what there is in the child's present that is usable with reference to it; how such elements are to be used; how his own 
knowledge of the subject-matter may assist in interpreting the child's needs and doings, and determine the medium in which the child should be placed in order that his growth may be properly directed. (Ibid., pp. 285-286)

If this view may not, in all fairness, be reduced to an understanding of the curriculum as a destiny, it does not exclude in principle the possibility of seeing it as 'mathematic': is an image of the curriculum as the arrangement of 'objects', mathemata, adequate for what is most vital in the Lipmanian and Sharpian undertaking? Once one wants to create a philosophical curriculum, that is, a curriculum to sustain the search for meaning and not (only) for positive knowledge (see Lipman, Sharp, \& Oscanyan, 1980), can one think of it as an organization of mathemata or is one led to embrace a different view? And is this change of view limited to a philosophical curriculum or, via the latter, may it finally concern any subject-matter? Does not the revolution that Lipman (1988) ascribes to the introduction of philosophy into the school amount precisely to this alteration of perspective?

I mean 'alteration' in a quasi-literal meaning: it is the idea that - as there is no truth without otherness - no curriculum (= no organization of the 'truth' within a specific domain of knowledge) is possible without the recognition of otherness, and principally of that other that the child is. Whenever, as in Dewey (or, better, in a Dewey uncharitably read), the relationship between the child and the curriculum is construed in terms of a unilinear process, the danger looms large that the otherness of the former is jeopardized and sacrificed on the altar of the truth. Instead, what is at stake in the very gesture of inventing the P4C curriculum is, at least in the interpretation here proposed, not so much the organization of a panoply of 'objects' (= themes consecrated by tradition, contents to be learnt etc.) as the re(dis)covery of the philosophical questioning thanks to the addressing of the child (where - along with the objective meaning of the genitive, which is more convergent with the 'Deweyan' view of the curriculum - we should hear the subjective meaning of the 
genitive: the child addresses the philosophical heritage and helps us 'resituate' it in the movement of questioning).

In this sense, Lipman and Sharp's undertaking breaks the 'Deweyan' mold or, to put it more accurately, it opens up the space to inhabit the Deweyan relation between the child and the curriculum in a different, 'altered' way. A meticulous scrutiny of the IAPC curriculum would show how this 'alteration' takes place (manifesting itself in a double dramatization, both of the curriculum and of the student, to adopt and adapt a phrase of Lipman [1995/1996]), ${ }^{8}$ but this cannot be performed in this context.

There are in the Deweyan conceptual device resources to avoid the aforementioned infelicitous outcome but, at the same time, it is legitimate to argue that the Lipmanian and Sharpian ulteriority - their endeavor to deploy philosophy (and not primarily science) for educating thinking, their acceptance of the model of inquiry but inflecting it towards the cultivation of the philosophical investigation and their building of a curriculum less as a repertoire of mathemata than as an invitation to wonder at the world - has provided a (Deweyan) way to go beyond Dewey.

By appropriating the title of the conference from which I have taken my cue ("Devir-criança da filosofia") - which is also a Deleuzian theme recurring in Kohan's work (see Kohan, 2015, esp. ch. 5) - it is possible to state that no philosophical curriculum (for children) is possible without a becoming-child of philosophy. And this, I would suggest, may end up being a more radical way of saying (with Dewey but beyond him) that, in the controversy of the child vs the curriculum, "[t]he case is of Child" (Dewey, 1976, p. 291).

Where Kohan and I part company is that, while I would tend to see this movement at work in the Lipmanian-Sharpian re-elaboration of the Deweyan heritage, he emphasizes how Lipman, ultimately maintaining 'a dogmatic image of

\footnotetext{
8 Being more cautious, one should aver that in the IAPC curriculum there lies a tension between this alteration - which, as argued here, originates in the very 'initiating' gesture of inventing a curriculum addressed at (and by) the child as a (philosophical) inquirer - and the persistence and resistance of a 'mathematic' thrust, which may be one of the sources of the reservations on Lipman's undertaking expressed by Kohan (and hinted at in the final paragraph of this paper).
} 
the child and the p4c curriculum

thought' (Kohan, 2014, pp. 37 ff.) and embracing the notion of a model of inquiry, risks preserving, despite his undeniable achievements, a Platonic stance (whose serious consequences impact also on the very construction of the curriculum [see the magnificent discussion in Waksman \& Kohan, 2013]). Whether these two positions represent irreconcilable alternatives and, to put it in an over-simplified slogan, whether we have to choose between Deleuze and Dewey, or whether we should operate in favor of a mutual cross-fertilization within a broader horizon, is an important question concerning the way in which we understand $\mathrm{P} 4 \mathrm{C}$ but one that, unfortunately, exceeds the scope of this paper. ${ }^{9}$

\section{references}

Alquié, F. (1950). La découverte métaphysique de l'homme chez Descartes. Paris: Press Universitaires de France.

Deledalle, G. (2002). Michel Foucault. Le tournant tunisien: du structuralisme à l'analyse pragmatique. Les cahiers de Tunisie 182: 45-51.

Descartes, R. (1908a [1637]). Discours de la Méthode. In Oeuvres de Descartes (vol. VI, pp. 178). Publiées par Ch. Adam \& P. Tannery. Paris: Léopold Cerf.

Descartes, R. (1908b [1639]). Meditationes de prima philosophia. In Oeuvres de Descartes (vol. VII, pp. 1-561). Publiées par Ch. Adam \& P. Tannery. Paris: Léopold Cerf.

Descartes, R. (1908c [1644]). Principia philosophiae. In Oeuvres de Descartes (vol. VIII: 1-329). Publiées par Ch. Adam \& P. Tannery. Paris: Léopold Cerf, 1908.

Dewey, J. (1976). The Child and the Curriculum. In The Middle Works of John Dewey, vol. 2: 1902-1903 (pp. 271-291). Edited by J.A. Boydston. Carbondale: Southern Illinois University Press.

Dewey, J. (1984a). The Quest for Certainty. In The Later Works of John Dewey, vol. 4: 1929. Edited by J.A. Boydston. Carbondale: Southern Illinois University Press.

Dewey, J. (1984b). Qualitative Thought. In The Later Works of John Dewey, vol. 5: 1929-1930 (pp. 243-262). Edited by J.A. Boydston. Carbondale: Southern Illinois University Press.

Dewey, J. (1986). How We Think. In The Later Works of John Dewey, vol. 8 (pp. 105-352). Edited by J.A. Boydston. Carbondale and Edwardsville: Southern Illinois University Press.

Dewey, J. (1988). Experience and Education. In The Later Works of John Dewey, vol. 13: 19381939 (pp. 1-62). Edited by J.A. Boydston. Southern Illinois University Press, Carbondale and Edwardsville.

Foucault, M. (2008). Le courage de la vérité. Le gouvernment de soi et des autres II. Cours au Collège de France, 1984. Paris: Éditions de Seuil/Gallimard.

\footnotetext{
${ }^{9}$ I would like to express my gratitude to the two anonymous reviewers for their insightful comments and valuable suggestions.
} 
Foucault, M. (2011). The Courage of the Truth (The Government of Self and Others II). Lectures at the College de France, 1983-1984. Transl. Graham Burchell. Basingtoke and New York: Palgrave Macmillan.

Heidegger, M. (1987). Die Frage nach dem Ding. Tübingen: Max Niemeyer Verlag.

Heidegger, M. (1994). Die Zeit des Weltbildes. In M. Heidegger, Holzwege (pp. 75-116). Frankfurt am Main: Vittorio Klostermann.

Kant, I. (1998). Beantwortung der Frage: Was ist Aufklärung?. In I. Kant, Werke, vol. 6. Schriften zur Anthropologie, Geschichtsphilosophie, Politik und Pädagogik. Darmstadt: Wissenschaftliche Buchgesellschaft.

Kennedy, D. (2006). Fools, Young Children, Animism, and the Scientific World-Picture. In D. Kennedy, Changing Conceptions of the Child from the Renaissance to Post-Modernity. A Philosophy of Childhood (pp. 69-78). Lewiston-Queenston-Lampeter: The Edwin Mellen Press.

Kohan, W.O. (2010). Não há verdade sem alteridade. A propósito de "Devir-criança da filosofia: infância da educação." In W.O. Kohan (ed.), Devir-criança da filosofia: infância da educação (pp. 7-13). Belo Horizonte: Autêntica.

Kohan, W.O. (2014). Philosophy and Childhood. Critical Perspectives and Affirmative Practices. New York: Palgrave Macmillan.

Kohan, W.O. (2015).Childhood, Education and Philosophy: New ideas for an old relationship. Abingdon, UK and New York: Routledge.

Lipman, M. (1995/1996). Philosophical Discussion Plans and Exercises. Analytic Teaching, 16(2), 64-77.

Lipman, M. (2008). A Life Teaching Thinking. Montclair, N.J.: IAPC.

Lipman, M., Sharp, A.M., Oscanyan, F.S. (1980). Philosophy in the Classroom, Temple University Press, Philadelphia.

Murris, K. (2016). The Philosophy for Children Curriculum: Resisting 'Teacher Proof' Texts and the Formation of the Ideal Philosopher Child. Studies in Philosophy and Education 35 (1): 63-78. DOI: https:// doi.org/10.1007/s11217-015-9466-3.

Oliverio, S. (2012). Accomplishing Enlightenment: Dewey's Inquiry, Childhood and Philosophy. Education \& Culture, 28(2), 54-69.

Oliverio, S. (2015). Lipman's Novels or Turning Philosophy Inside-Out. Childhood \& Philosophy, 11(21), 81-92.

Rabinow, P. (2011). Dewey and Foucault: What's the Problem?. Foucault Studies 11: 11-19. DOI: https://doi.org/10.22439/fs.v0i11.3202.

Rabinow, P. (2012). How to Submit to Inquiry: Dewey and Foucault. The Pluralist 7 (3): 25-37. DOI: https://doi.org/10.5406/pluralist.7.3.0025.

Renier, S. (2016). The Many Lives of John Dewey's Democracy and Education. European Journal of Pragmatism and American Philosophy VIII (1). DOI: https://doi.org/10.4000/ejpap.448.

Rorty, R. (1986). Introduction. In The Later Works of John Dewey, vol. 8 (pp. ix-xviii). Edited by J.A. Boydston. Carbondale and Edwardsville: Southern Illinois University Press.

Striano, M., \& Oliverio, S. (2012). Philosophy for Children: An Educational Path to Philosophy. Thinking: The Journal of Philosophy for Children, 20, 31-41.

Striano, M. (2012). Philosophy as Education for Thinking. A Pedagogical Conversation with Matthew Lipman. In M. Santi \& S. Oliverio (eds.), Educating for Complex Thinking 
the child and the p4c curriculum

through Philosophical Inquiry. Models, Advances, and Proposals for the New Millennium (pp. 519-525). Napoli: Liguori.

Toulmin, S. (2001). Return to Reason. Boston: Harvard University Press.

Waksman, V., \& Kohan, W.O. (2013). Fare filosofia con in bambini. Strumenti critici e operativi per il lavoro in classe con e oltre il curricolo Philosophy for Children. Edizione italiana a cura di Marina Santi. Napoli: Liguori.

received in: 18.11 .19

approved in: 08.12 .19 